Revista de Journal of Integrated
GESTÃO COSTELRA Integrada COSTALZONE MANAGEMENT

\title{
Management and research on plastic debris in Uruguayan Aquatic Systems: update and perspectives
}

\author{
Juan Pablo Lozoya ${ }^{\mathrm{a}} @$; Alvar Carranza ${ }^{\mathrm{b}, \mathrm{e}}$; Javier Lenzic ${ }^{\mathrm{c}}$ Emanuel Machín ${ }^{\mathrm{d}}$; Franco Teixeira de Mello \\ Silvana González; ; Daniel Hernández ${ }^{\mathrm{g}}$; Gissell Lacerot ${ }^{\mathrm{h}}$; Gastón Martínez ${ }^{\mathrm{f}}$, i; Fabrizio Scarabino ${ }^{\mathrm{f}}$; \\ José Sciandro ${ }^{\mathrm{a}}$; Gabriela Vélez-Rubio ${ }^{\mathrm{j}, \mathrm{k}}$; Fernanda Burgues ${ }^{\mathrm{d}}$; Daniel Carrizo ${ }^{1}$; Felipe Cedrés ${ }^{\mathrm{m}}$; \\ Julio Chocca ${ }^{\mathrm{f}}$; Daniel de Álava ${ }^{\mathrm{a}}$; Sebastián Jiménez ${ }^{\mathrm{c}}$, ${ }^{\mathrm{f}}$, Valentina Leoni ${ }^{\mathrm{b}}$; Pablo Limongi ${ }^{\mathrm{m}}$; \\ Guzmán López $^{\mathrm{f}}$; Yamilia Olivera ${ }^{\mathrm{m}}$; Mariana Pereira $^{\mathrm{m}}$; Luis Rubio ${ }^{\mathrm{n}}$; Federico Weinstein ${ }^{\mathrm{m}}$
}

\begin{abstract}
Synthetic plastics have become an indispensable component of modern life, and the amount of plastics disposal has increased dramatically as a result. With human population increasing, it is expected that the prevalence of plastic debris in the environment will also increase, unless sustainable daily habits are incorporated, waste management improved, and new alternative materials are discovered and popularized. To date, several reports show negative effects of plastic debris on marine and freshwater fauna (e.g. invertebrates, birds, turtles, marine mammals). Plastic are ubiquitous in the water column, deposited

@ Corresponding author, to whom correspondence should be addressed: <jplozoya@gmail.com>

${ }^{a}$ Universidad de la República (UDELAR), Centro Interdisciplinario para el Manejo Costero Integrado del Cono Sur (MCISur), Centro Universitario de la Región Este (CURE), Maldonado, Uruguay.

${ }^{\mathrm{b}}$ Museo Nacional de Historia Natural, Área Biodiversidad \& Conservación, Montevideo, Uruguay.

${ }^{\mathrm{c}}$ Centro de Investigación y Conservación Marina (CICMAR), Uruguay.

${ }^{\mathrm{d}}$ Universidad de la República (UDELAR), Facultad de Ciencias, Montevideo, Uruguay.

${ }^{\mathrm{e}}$ Universidad de la República (UDELAR), Centro Universitario de la Región Este (CURE), Departamento de Ecología Teórica y Aplicada, Maldonado, Uruguay

${ }^{\mathrm{f}}$ Ministerio de Ganadería Agricultura y Pesca (MGAP), Dirección Nacional de Recursos Acuáticos (DINARA), Montevideo, Uruguay.

${ }^{\mathrm{g}}$ Universidad de la República (UDELAR), Facultad de Ciencias, Departamento de Ecología y Evolución, Montevideo, Uruguay.

${ }^{\mathrm{h}}$ Universidad de la República (UDELAR), Centro Universitario de la Región Este (CURE), Ecología Funcional de Sistemas Acuáticos, Rocha, Uruguay.

${ }^{\mathrm{i}}$ Universidad de la República (UDELAR), Centro Universitario de la Región Este (CURE), Grupo de Estudios Pesqueros y de Impacto Ambiental, Rocha, Uruguay.

${ }^{\mathrm{j}}$ University of Valencia, Cavanilles Institute of Biodiversity and Evolutionary Biology, Marine Zoology Unit, Valencia, Spain.

k ONG Karumbé, Montevideo, Uruguay.

${ }^{1}$ Queen's University, Institute for Global Food Security, Belfast, U.K.

${ }^{\mathrm{m}}$ Universidad de la República (UDELAR), Centro Universitario Regional Este (CURE), Maldonado, Uruguay.

${ }^{\mathrm{n}}$ Proyecto FREPLATA, Ministerio de Vivienda, Ordenamiento Territorial y Medio Ambiente (MVOTMA), Uruguay.
\end{abstract}

* Submission: 2 FEB 2015; Peer review: 27 MAR 2015; Revised: 23 APR 2015; Accepted: 7 MAY 2015; Available on-line: 8 MAY 2015
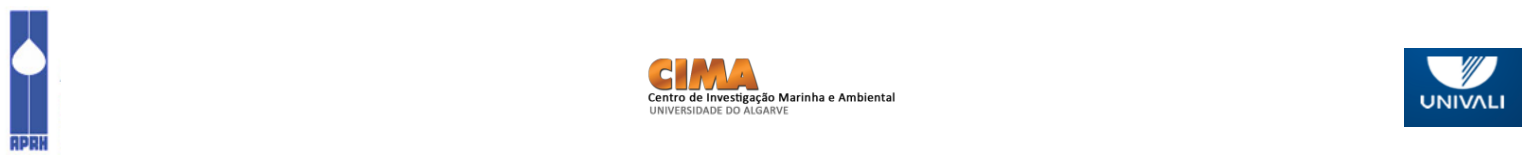
in fine sediments and enter the guts, respiratory structures and tissues of different aquatic species, and are incorporated into food webs via ingestion. This global problem also affects beach and near-shore activities (e.g. tourism, fisheries, and aquaculture) with negative social and economic consequences. The research of plastics effect on aquatic environments in Uruguay is only incipient. With the aim of contributing to scientific knowledge, decision-making and the management of plastic debris, here we reviewed the available information on plastic debris sources, their impacts on biodiversity, and policy issues in Uruguayan aquatic systems. Moreover, we reviewed and systematized community outreach initiatives, and examined national policies and management initiatives. We found that Uruguayan aquatic systems (freshwater, coastal marine and benthic) are affected by plastic pollution, both from land-based and sea-based activities, although national-level policies are modern and well suited for minimizing the impacts of plastic pollution. We reviewed biota-plastic debris interactions, and found evidence for impacts on a number of aquatic taxa, including the poorly reported ingestion of microplastics in freshwaters fishes and the association with plastic benthic debris. Global and regional hydrographic settings (Río de la Plata Estuary), as well as idiosyncratic ecological, socio-economic and cultural issues, make Uruguay a valuable test-site for this topic. Our ultimate goal is to minimize the effects of this widespread environmental, economic, health and aesthetic problem.

Keywords: Plastic and microplastic pollution, Río de la Plata, Aquatic systems, Integrated Coastal Zone Management, Waste management, Uruguay.

\section{Resumo}

\section{Pesquisas e manejo de descartes plásticos em sistemas aquáticos uruguaios: atualização e perspectivas}

Produtos plásticos tem se tornado um componente indispensável na vida moderna, como conseqüencia disso a quantidade de plásticos descartados tem dramaticamente aumentado. É esperado que com o aumento da população de seres humanos a prevalência de descartes plásticos também aumente, a menos que hábitos cotidianos sustentáveis sejam incorporados, e novos materiais alternativos sejam descobertos e popularizados. Até o momento, diversas pesquisas têm mostrado os efeitos negativos de descartes plásticos sobre a fauna marinha e dulcícola (p. ex.: invertebrados, aves, tartarugas e mamíferos marinhos). Em ambientes aquáticos, plásticos estão em toda parte: na coluna de água, depositados em sedimento fino e dentro de estômago, estruturas respiratórias e tecidos de diversas espécies aquáticas, e são incorporadas nas teias alimentares através da ingestão. Este problema global também afeta atividades realizadas na praia e próximas à costa (p. ex.: turismo, pesca, e aqüicultura) com conseqüencias sociais e econômicas negativas. Pesquisas que abordem os efeitos de plásticos sobre ambientes aquáticos no Uruguai é ainda incipiente. Com o objetivo de contribuir para o conhecimento científico, a tomada de decisões e o manejo de descartes plásticos, revisou-se a informação disponível acerca de fontes de descartes plásticos, observando os impactos delas sobre a biodiversidade e sobre questões políticas em sistemas aquáticos uruguaios. Além disso, revisou-se e sistematizou-se o alcance de iniciativas da comunidade, e examinou-se a política nacional de iniciativas de manejo. Descobrimos que os sistemas aquáticos uruguaios (de água doce, costeiros e marinhos bentônicos) são afetados pela poluição de plástico, pelas atividades terrestres e pelas atividades ligadas ao mar, embora as politicas a nível nacional sejam modernas e bem adaptadas para minimizar os impactos dessa poluição. Revisamos as interações biota-detritos plásticos, e encontramos evidência de impactos sobre diversos taxa aquáticos, incluindo a ingestão de microplástico per peixes de água doce, e da associação que existe entre biota e os detritos plásticos bentônica, geralmente pouco relatados. As configurações hidrográficas globais e regionais (Estuário Rio de la Plata), bem como questões ecológicas idiossincráticas, sócio-econômico e culturais fazem do Uruguai um valioso lugar-teste para este tópico. O objetivo final dessa pesquisa é minimizar os efeitos deste amplamente difundido problema de saúde, ambiental, econômico e estético.

Palavras-chave: Contaminação por plásticos e microplásticos, Rio de la Plata, Gestão Costeira Integrada, Gestão de resíduos, Uruguai.

\section{Introduction}

Plastics are a relatively new material, since the first man-made plastic was presented by Alexander Parkes at the 1862 Great International Exhibition in London (NPR, 2009). Even though the use and production of plastic date from early 20th century, its production and consumption did not really take off until after World War II (Dubois, 1972; NPR, 2009). Due to its versatility, resistance and low cost, plastics became widely used, increasing its annual global production from 1.7Mtones to 280Mtones within the last 60 years (Lechner et al., 2014). Thus, in a short time, plastics have become a major component of modern debris (Andrady \& Neal, 2009).

Although plastics are theoretically recyclable, a huge amount is simply dumped awaiting their natural long- lasting degradation (Moore, 2008; Barnes et al., 2009). During this process plastic debris find their path to waterways and, through streams, rivers, and lakes discharge into coastal seas and oceans (Murray, 2009; Moore et al., 2011; Rech et al., 2014).

Plastic debris does not only come from land-based activities. For instance, fishing fleets, maritime traffic, and the increasing human populations in coastal zones are also important sources of marine debris (Ribic et al., 2010). It is estimated that fishing activities are responsible for ca. $20 \%$ of plastic debris (Andrady, 2011), not only because of "throw away" behavior, but also because of fishing gears (e.g., nets, longlines) missed or forsaken at sea (Bullimore et al., 2001; Tschernij \& Larsson, 2003). Further, accidental dumping due to negligence of ship operators (e.g. 
garbage, raw materials) are an important source of debris such as resin pellets used for plastic manufacturing (Mato et al., 2001; Moore, 2008). Recreational activities also produce plastic pollution, mainly due to irresponsible individual actions, such as the deliberate release of garbage into the environment (Murray, 1996).

In this vein, plastic pollution in aquatic ecosystems is one of the most significant global environmental problems, determining multiple ecological consequences (Thompson et al., 2009), which are not yet completely understood. Besides the aesthetic problem, the adverse effects on marine and freshwater fauna are evident (e.g. invertebrates, fish, birds, turtles and mammals) (Azzarello \& van Vleet, 1987; Laist, 1997; Clapham et al., 1999; Erikson \& Burton, 2003; OSPAR, 2009; Boerger et al., 2010). The most harmful consequences reported so far are related to entanglement, ingestion, and species distribution (Pierce et al., 2004; Thompson et al., 2009). The entanglement is probably one of the most common consequences of plastics debris (e.g. with fishing gears), affecting mobility, natural behavior and/or asphyxia (e.g., sharks, seals).

Plastic ingestion has been widely documented, and its physical consequences include asphyxia, reduced nutrient assimilation, and obstruction and perforation of digestive tracts (Derraik, 2002; Mascarenhas et al., 2004; Rios \& Moore, 2007; Mallory, 2008). However, less is known about microplastic ingestion and its role in aquatic trophic webs. Due to solar radiation and erosion, plastic debris suffer photochemical and mechanical degradation with time, generating milimetric to microscopic particles (Andrady, 2003; Moore, 2008; Cole et al., 2011). These resulting microplastics (i.e. smaller than $5 \mathrm{~mm}$, Arthur et al., 2009), are of great current concern since they occur in freshwater and ocean ecosystems worldwide (Barnes et al., 2009; Sutherland et al., 2010; Andrady, 2011; Cózar et al., 2014; Eriksen et al., 2014). Recently, microplastic particles have been identified as a good substrate for Persistent Organic Pollutants (POPs) like DDT, PCBs, $\mathrm{HCHs}$ and nonylphenol, among others.

Although POPs usually present low concentrations in seawater, mainly due to their hydrophobic condition, these pollutants can be progressively adsorbed into plastic bits, increasing their concentration up to several orders of magnitude (Mato et al., 2001; Teuten et al., 2007; 2009; Frias et al., 2010; Hirai et al., 2011). These microplastics (and their adsorbed POPs) could be ingested by several animals such as amphipods, barnacles, clams, tubeworms, fishes and sea birds, and thus pollutants could be transferred to their tissues (Teuten et al., 2007; Farrell \& Nelson, 2012; et al., Foekema et al., 2013; Tanaka et al., 2013). Therefore, the ingestion of microplastics may cause the spread of hazardous pollutants with endocrine disruptive capacities through food webs, via bio-magnification processes. However, current empirical evidence of this phenomenon in natural environments is not yet conclusive, and further research is needed (e.g., Koelmans et al., 2014). As a consequence, POPs could climb up to the top of the food chain, and species of higher trophic levels magnify the concentration of contaminants in their tissues (Mato et al., 2001; Teuten et al., 2009; Tanaka et al., 2013). Both the presence of microplastics in seafood and the potential toxins associated with them can pose a significant food safety hazard, but the risk estimation for humans has not been established yet (van Cauwenberghe \& Janssen, 2014).

The massive increase in plastic floating debris in the marine environment may also have a significant impact on species distribution, particularly due to the transport of exotic species (Barnes \& Fraser, 2003; Barnes \& Milner, 2005; Murray, 2009) which could probably affect native marine diversity (Derraik, 2002). In marine environments, microplastics can moreover carry fouling organisms like diatoms, invertebrates and bacteria, creating a new pelagic habitat for these species (Reisser et al., 2014). Rafting dispersal, involving organisms associated with floating objects of either natural or anthropogenic origin, is particularly relevant in a climate change scenario, where significant changes in species distribution limits are expected (Astudillo et al., 2009; Bravo et al., 2011; Farrapeira, 2011; Thiel et al., 2011).

Despite the mounting evidence pointing at the negative consequences of aquatic and coastal plastic pollution, this pressing issue has not been analysed in the main scientific literature for our study area. In turn, and looking forward to manage anthropogenic marine debris, key information is lacking in order to contribute from science to decision making. In this vein, the objectives of this paper are to review, synthesize and summarize available data on sources, impacts in biodiversity and policy issues on plastic debris in Uruguayan aquatic systems.

\section{Material and methods}

\subsection{Plastic debris in Uruguayan aquatic systems: an overview}

With the aim of fostering an integrated and multidisciplinary approach to this issue in Uruguay, an overview of existing information has been performed. To this end, different research groups, currently working on different aspects of plastic debris, were summoned during 2014 ( $1^{\text {st }}$ Workshop, and $1^{\text {st }}$ Symposium on plastic debris in Uruguayan aquatic systems), reviewing and compiling their main results and investigations.

Given that this field of research is still incipient in Uruguay, with only a few refereed scientific papers pub- 
lished to date, unpublished observations and preliminary results of ongoing research were also included in this review. Although we are confident that several of these preliminary results will be published shortly, we are aware of the significant importance of peer review processes for their scientific validation. However, considering the importance of the problem addressed and the main objective of this review, we consider that the value of such observations and preliminary results justify their inclusion.

In the next section main sources and pathways of plastic debris into Uruguayan aquatic environments were analyzed. The two main origins (i.e. land and ocean) have been assessed and results are presented in three main categories: Urban waste, addressing waste management and landfills; Waterways and specially the Río de la Plata Estuary; and Marine traffic in Uruguayan waters based on satellite Automatic Identification System (AIS, Maltenoz Limited). In the second section the main ongoing assessments of plastic debris in Uruguay are described, covering Coastal debris focused on beaches, and Benthic marine and estuarine debris covering the Río de la Plata Estuary, and the inner $($ depth $<50 \mathrm{~m})$ and outer $($ depth $>50 \mathrm{~m})$ Uruguayan continental shelf. The third section refers to interactions between plastics debris and aquatic biota, while the last section, Policy, address international and regional agreements on marine pollution prevention, as well as Uruguayan laws and regulations on plastic management.

\subsection{Sources and pathways}

\section{a) Urban waste}

The capital city of Uruguay, Montevideo, and its Metropolitan Area has an estimated population of 2 million people, which represents more than $60 \%$ of the Uruguayan population. According to the Solid Waste Master Plan of Montevideo and its Metropolitan Area (SWMPM), urban waste generation fluctuates between 0.38 and $0.62 \mathrm{~kg} /$ person/day (FICHTNER-LKSURAsociados, 2004). In 2003, the formal system collected 850 tons/day of waste, while the informal sector was responsible for 696 tons/day. The $57 \%$ of the latter is primarily marketed for recycling and sold in neighbourhood markets, while organic materials are used for pork food or delivered to the Municipal treatment plant of organic wastes. Of the $43 \%$ remaining, $30 \%$ is finally disposed in landfills but the remaining $13 \%$ has an unknown final destination (FICHTNER-LKSUR-Asociados, 2004).

Plastic materials were the second most important element $(14 \%)$ of urban waste in Montevideo and its Metropolitan Area (Figure 1), covering several categories: plastic films $(10 \%)$, PET $(2 \%)$, non-classified plastics $(1 \%)$, and rigid plastics (1\%) (FICHTNER-LKSURAsociados, 2004). However, plastics were not a very important item within the recycling market, reaching only the $6.2 \%(8,334$ tons and 11,000 tons in 2003 and 2004, respectively) of the total recyclable materials (FICHTNER-LKSUR-Asociados, 2004).

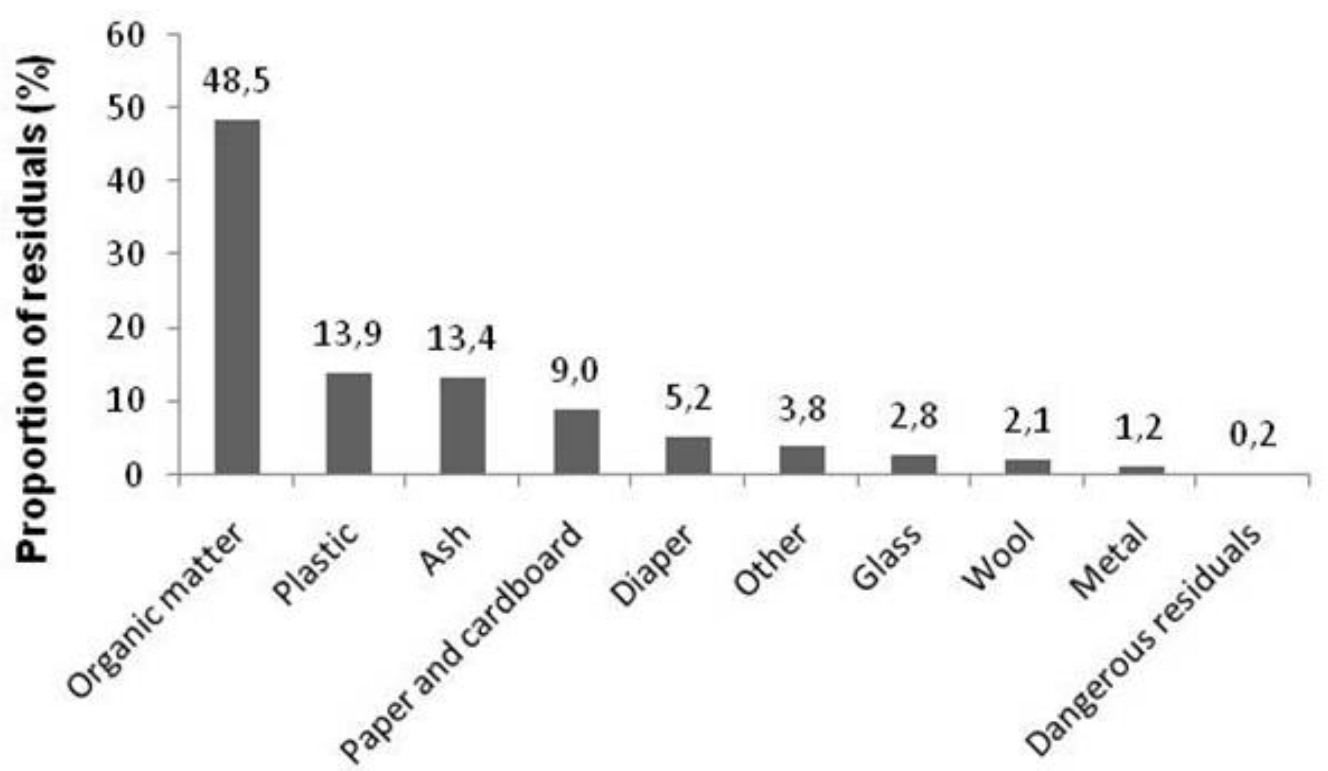

Figure 1 - Distribution of waste items in Montevideo and the metropolitan area according to FICHTNER-LKSUR-Asociados (2004).

Figura 1 - Distribuição de itens dos resíduos em Montevidéu e na região metropolitana de acordo com FICHTNER-LKSUR-Asociados (2004). 


\section{b) Waterways}

The SWMPM also highlights another dimension to be considered in Uruguayan waste management processes: the short distance between landfills and waterways. River runoff has been identified as one of the main pathways for the entrance of anthropogenic litter from land-based sources into coastal beaches and marine environments (Derraik, 2002; Moore et al., 2011; Rech et al., 2014). This litter (abundance and composition) is mainly determined by land uses and social and economic activities in the basin, including transit of boats and ships, urban and rural run-off, effluents from sewage plants, and dumping at riversides (Lechner et al., 2014; Rech et al., 2014 and references therein).

In Uruguay, the arrival of litter in local waterways seems to occur throughout the waste management process, but especially in the final disposal of waste (e.g. open sky dumpsters or landfills). There, both the informal sector and neighbours spill debris in the waterways or along the coasts. Similarly, the growing presence of unregulated landfills near creeks and streams increases the possibility of plastic waste entering to waterways considerably (Figure 2a and 2b). Therefore, landfills would be a source of plastic materials to aquatic ecosystems, reinforced by the insufficient sweeping of cities, and the reduced awareness of the majority of the population that contributes to this contamination. This is in line with the general pattern, where plastics are the most important item in riverside litter (e.g., Moore et al., 2011; Lechner et al., 2014; Rech et al., 2014).

The analysis of the mean distance (in meters) to the nearest river or stream for 23 Uruguayan open sky dumps showed that two of them were placed on waterways or were discharging their leakages directly into a waterway, while another 13 were placed less than $300 \mathrm{~m}$ from the nearest stream (Figure $2 \mathrm{c}$ ). These results could be suggesting that the Uruguay River and Río de la Plata Estuary would be directly affected by plastic contamination originated in landfills. Furthermore, the coastal area that includes these basins is the most populated area in Uruguay (i.e., 1.7 million people). Providing several ecosystem services, and holding different productive and industrial sectors, this coastal area is of utmost social, environmental, and economic relevance (e.g. tourism, fisheries).

However, from the point of view of regional management, this 'local' plastic contamination could seems 'insignificant' considering that the Río de la Plata drains the second largest basin in South America. Nonetheless, this fact cannot be used as an excuse justifying failure in waste management or passivity against this serious problem, but to increase regional (and international) collaborations regarding management of plastic debris. With more than $3,000,000 \mathrm{~km}^{2}$, this basin is (Teuten et al., 2007; Farrell \& Nelson, 2012;
Foekema et al., 2013 about one fourth of the continent's surface (e.g., Framiñan \& Brown, 1996; Guerrero et al., 1997), including areas of southeastern Bolivia, southern and central Brazil, the entire nation of Paraguay, most of Uruguay, and northern Argentina. The main rivers of the La Plata basin are the Paraná, one of the longest in the world, and its main tributary, the Paraguay River, and the Uruguay River (Mianzan et al., 2001). Although Uruguayan coastal and riverside population does not exceed 3 million persons, only Buenos Aires Province (Argentina) is home for 15.6 million people (2010). Moreover, the Rio de la Plata Estuary is also the maritime access to the 'Hidrovia', a highly complex fluvial system that communicates to the Amazon Basin, and represents a key waterway for the flow of goods and commodities between the major port cities of the region. Thus, within this hydrographic setting, Uruguayan (and Buenos Aires Province) aquatic environments, and in particular the Río de la Plata Estuary, could be considered as a sink area receiving nearly one fourth of the South American continental runoff.

This setting could be even worse if we consider that according to Acha et al. (2003), the Río de la Plata is characterized by a bottom salinity front that acts as a barrier accumulating debris. On average, the Rio de la Plata discharges about $23,000 \mathrm{~m}^{3} / \mathrm{s}$ of freshwater and supply of $80 \times 10^{6} \mathrm{t} /$ year of sediment into the western South Atlantic (Giberto et al., 2004; Piola et al., 2008). The Río de la Plata estuary is a two-layer system with a semi-permanent salt wedge and freshwater flows seawards over the surface (Burone et al., 2013). This salt wedge intrusion creates a well-stratified section characterized by two salinity fronts: the bottom salinity front in the innermost part of the bottom salt wedge, and the surface salinity front in the transition between the turbid river and the less turbid marine waters.

Near the former, and generated by the opposing river discharge, incoming tide, and wave and tidal current resuspension processes, a maximum turbidity zone (MTZ) can be found. This MTZ is characterized by a high suspended matter concentration and a large portion of the transported solids can flocculate here (Framiñan \& Brown, 1996; Framiñan et al., 2008; Burone et al., 2013). These estuarine processes may cause an increase of floating and sank debris in this area.

But these 'sink conditions' in the region can even be reinforced by oceanic processes occurring at large spatial scales in the Uruguayan Shelf. The South-western Atlantic Margin (SAM, Atlantic Ocean) is recognized as one of the most productive regions in the world, and this is mainly due to the Brazil-Malvinas Confluence (BMC), resulting from the convergence of the Southward-flowing Brazil Current (BC) and the northward flowing Malvinas Current (MC) (Ortega \& Martínez, 2007; Schmid \& Garzoli, 2009). This large- 

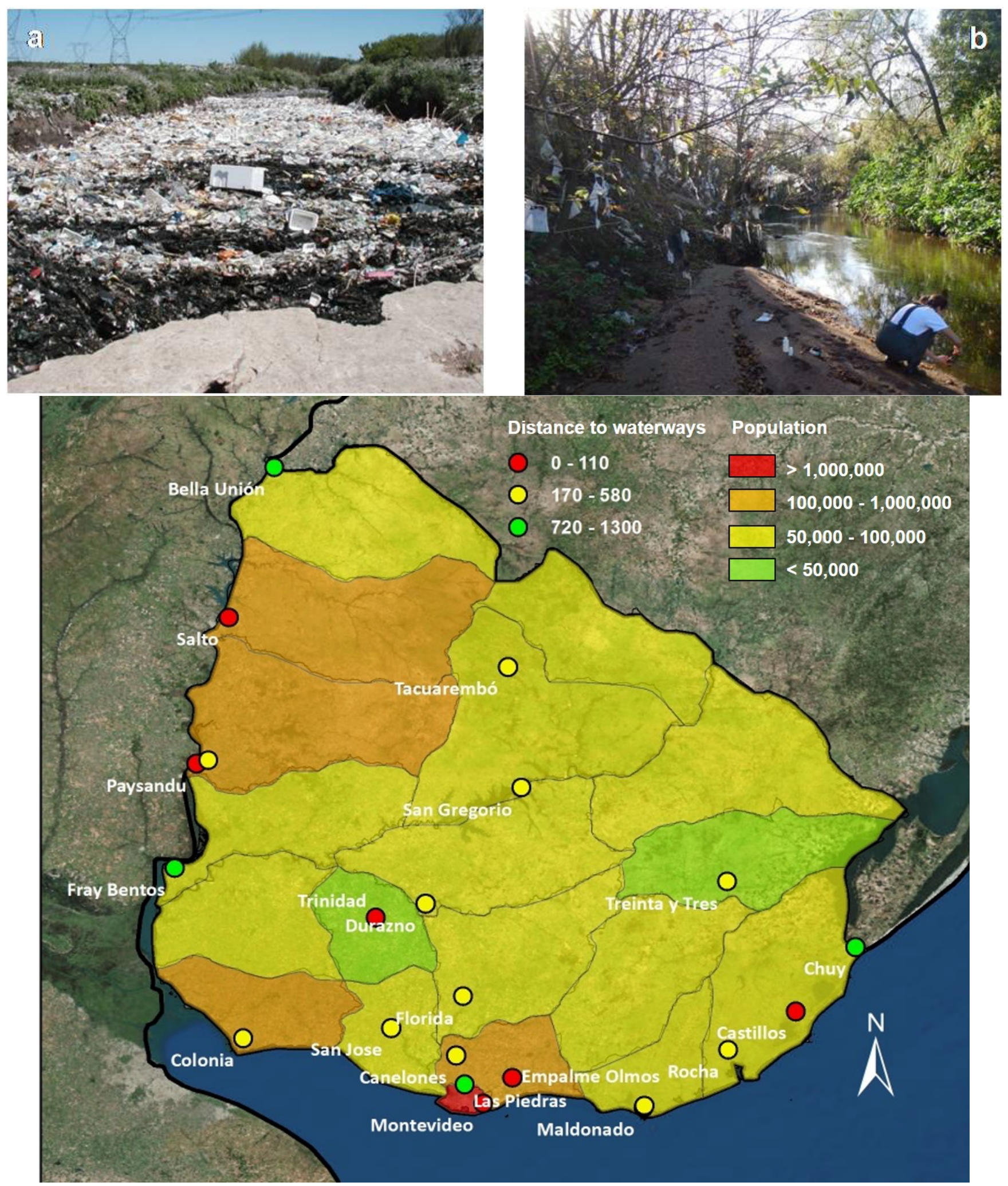

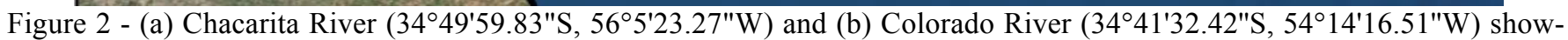
ing how landfills near streams increases the possibility that plastic wastes arrive to waterways (courtesy of Mello, L. and Grifero, L. \& Teixeira de Mello, F., resp.); (c) Map showing the spatial location of urban open dumps of the major cities in Uruguay, its distance to the closest waterway (colored circles), and the population of the different Municipalities.

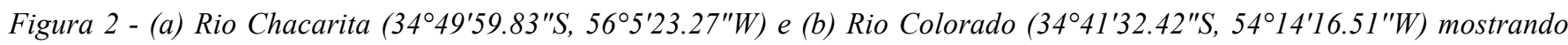
como aterros perto de córregos aumentam a possibilidade de que os resíduos de plástico chegam às vias navegáveis (cortesia de Mello, L. e Grifero, L. \& Teixeira de Mello, F., resp.); (c) Mapa mostrando a localização espacial dos lixões urbanos das principais cidades do Uruguai, a sua distância para a via navegável mais próximo (círculos coloridos), e a população dos diferentes municípios. 
scale oceanographic process presumably traps floating items and may enhance sedimentation rates (e.g., Franco-Fraguas et al. 2014).

\section{c) Marine traffic}

Globally, ship-generated debris constitutes a major portion of garbage, mainly in remote coasts and marine seafloor (CSW, 1995; Mann, 2006). This includes debris from cargo, passenger, commercial fishing, naval, research and recreational (sailboats and yachts) vessels, and also offshore oil and gas platforms. Regarding solid waste, vessels operating at sea produce different types of garbage that can be classified into domestic, which includes food, food packaging and other wastes related to crew activities (e.g. cigarettes, personal care items) and operational waste, related to the specific purpose or activity of the vessel (e.g., packaging, fishing gears, dispensable research instruments).

As has been mentioned above, the Río de la Plata Estuary constitutes the maritime access to the highly complex fluvial system named 'Hidrovia' that communicates with the Amazon Basin and hosts the Port of Montevideo. Located in the middle of a bi-oceanic Atlantic-Pacific corridor, the Port of Montevideo is one of the main centres of cargo movement in the MERCOSUR and South America (ca. 200M inhabitants) (ANP, 2014). In this vein, as a proxy of possible oceanbased debris sources in Uruguayan waters, the number of vessels occurring in Uruguayan waters has been estimated and mapped, based on marine traffic records from the satellite Automatic Identification System (AIS, provided by Marine traffic Maltenoz Ltd). Daily positions of each vessel which operated in Uruguayan waters were considered to generate a density map based on the accumulated presences (sum of daily occurrences) in a one-year period (July 2012-June 2013) for grids of $1.0 \mathrm{~nm}$ side (Figure 3).

In order to sketch the composition of marine traffic in Uruguayan waters, information on vessel's type/ /category from AIS database was examined, and missing or doubtful information was checked and completed using the Maritime Mobile Service Identity (MMSI) number of each ship as a reference. Additionally, statistics on vessel arrivals to the ports of Montevideo and Nueva Palmira from 2009 to 2014 were analyzed from available data of the National Agency of Ports (ANP) website (ANP, 2014).

Based on AIS data for the period June 2012-July 2013, 4,756 different ships were recorded operating in Uruguayan waters, with a monthly average of 1,157 ships. Regions of high intensity of traffic were mainly associated to the port and 'Hidrovia' access, services and power connection areas, as well as fishing grounds (Figure 3). Vessels operating in Uruguayan waters in this period were mostly cargo vessels $(77 \%$, e.g., container, bulkers, tankers, and other transporters), Industrial fishing vessels $(8 \%)$, port service ships $(6 \%$, e.g., pilots, tugs, port tenders and other small ships), and

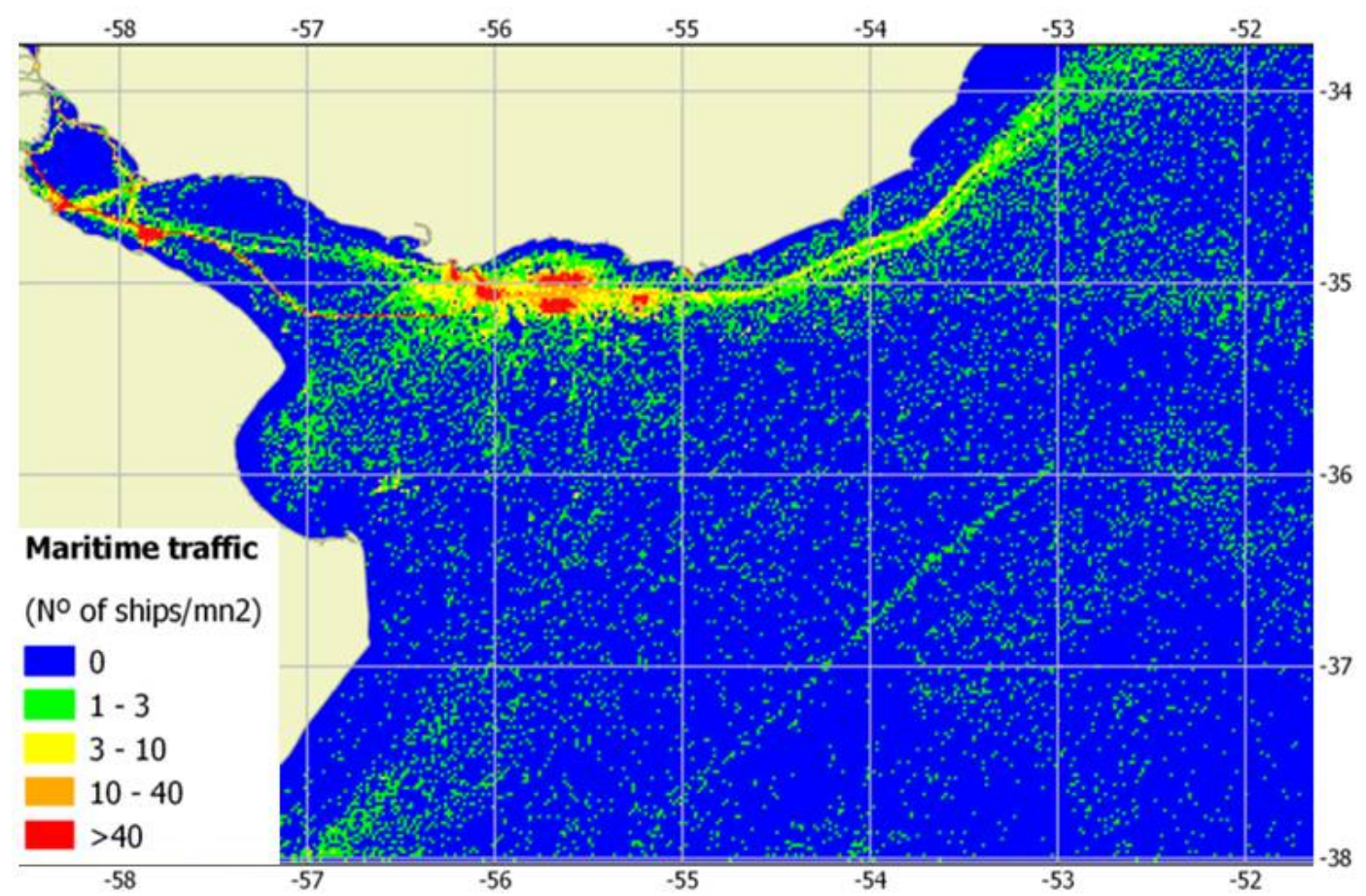

Figure 3 - Density map of vessel occurrences in Uruguayan waters represented as the accumulated daily presences of ships from June 2012 to July 2013 per cell (1.0nm side).

Figura 3 - Mapa de densidade das ocorrências de navios em águas uruguaias, representadas como as presenças diárias acumuladas de navios a partir de junho de 2012 a julho de 2013 por célula (1,0 nM per lado). 
Table 1 - Categories of vessels operating in Uruguayan waters for a year-round period (July 2012 to June 2013) obtained from satellite Automatic Identification System (AIS).

Tabela 1 - Categorias de navios operando em águas uruguaias ao longo de um ano (Julho de 2012 a Julho de 2013). Dados obtidos pelo sistema satelitário de identificação automática (AIS).

\begin{tabular}{lcc}
\hline Categories of ships & Number & $\mathbf{\%}$ \\
\hline Cargo vessels & 3,649 & 76.7 \\
\hline Commercial fishing & 389 & 8.2 \\
\hline $\begin{array}{l}\text { Port service (Pilot, port tender and tug } \\
\text { vessels) }\end{array}$ & 274 & 5.8 \\
\hline Passenger & 114 & 2.4 \\
\hline Recreational boating & 105 & 2.2 \\
\hline Uruguayan army and coast guard & 75 & 1.6 \\
\hline Undetermined & 60 & 1.3 \\
\hline Research and other offshore vessels & 35 & 0.7 \\
\hline Dredger & 30 & 0.6 \\
\hline Offshore oil and gas operations & 25 & 0.5 \\
\hline TOTAL & $\mathbf{4 , 7 5 6}$ & $\mathbf{1 0 0}$ \\
\hline
\end{tabular}

passenger ships $(2 \%$, e.g., high speed ferries and cruises) (Table 1).

In the period 2009-2013 there were in average 4,600 annual arrivals to the Port of Montevideo with an annual mean of 55Mgross register tonnage (GRT, ANP, 2014). For this period, arrivals included industrial fishing vessels $(40 \%)$, container vessels $(19 \%)$ and passenger ferries $(15 \%)$. In terms of GRT the $60 \%$ was composed of container ships and $11 \%$ by cruises. The ca. 750 artisanal fishing boats operating in the Uruguayan coast of the Río de la Plata and the Atlantic Ocean (Puig et al. 2010) should also be considered. Although having a smaller size than the industrial fleet, artisanal fisheries might also be an important source of plastics debris especially in the coastal zone.

The international shipping regulation (MARPOL Annex $\mathrm{V})$ prohibits the dumping of plastics in the sea by all types of ships, regulates the disposal of other garbage (food, domestic and operational wastes) and requires ports to provide garbage reception facilities for them (see International agreements on marine pollution prevention in the next section). Actually, waste is removed from the port by private companies, and transported to the municipal landfill of Montevideo. Currently lacking, accurate estimates of the amount of garbage produced in the sea, the proportion discarded at sea, incinerated onboard as well as landed for final disposal, are necessary for the development of waste management plans and actions by municipal and port authorities. These are of utmost importance taking into account that the port of Montevideo is developing a regional logistics strategic project that will strengthen its position as a regional hub port (Uruguay XXI Sector Logístico, 2013).

\subsection{Assessments of plastics debris in Uruguay}

\section{a) Coastal debris}

The Ocean Conservancy's International Coastal Cleanup Day is carried out in almost 100 countries all over the world. In its reports, 43 items are listed in five debris-producing activities (i.e., Shoreline \& Recreational, Ocean/Waterway, Smoking-related, Dumping, and Medical/Personal hygiene), according to the behavior associated with the production of debris. In Uruguay, Shoreline \& Recreational activities account for $74 \%$ of the total items collected, while Ocean/ /Waterway account for the 7\%.

In this line, most of plastic debris in Uruguayan urban coastal environments (i.e. those sampled in the Coastal Cleanup Day), are likely coming from autochthonous sources. By quantitative comparative purposes, data from the Ocean Conservancy's Coastal Cleanup Day 2011 were used to generate a Standardized Ocean Trash Index (SOTI). In order to account for country-level biases, area and volunteer effort were included in a single index. Thus, the SOTI results represented in Figure 4 show the total weight of debris (in pounds) collected per coastal mile, per volunteer, per day.

According to the results, Uruguay seems not to be among the countries most affected by the presence of coastal debris. However, these results are just for certain locations, on a certain day, and without considering e.g. the frequencies of beach cleaning activities which are yearly (or even daily) performed. Thus, even when the Coastal Cleanup Day is important to raise awareness about waste and plastic debris in aquatic and coastal systems, these estimates may not be a meaningful proxy of the amount of debris at a country level basis. It seems therefore crucial to supplement these results with scientific studies that quantify plastic and other debris on beaches, consider official data of mechanical cleaning in major urban beaches, or adopt a watershed-based approach including rivers arriving to the coastal areas.

In this regard, results from a project currently conducted on beaches of Punta del Este (Maldonado, Uruguay) suggest that in agreement with other studies (e.g. Martins \& Sobral 2011; Portz et al., 2011; Jayasiri et al. 2013), the smaller fraction plastics debris (i.e. microplastic $<5 \mathrm{~mm}$ ) are widely represented at beaches (Weinstein et al., 2014a; b). Besides evaluating the distribution, type and volume of microplastics, this project will address for the first time the link between persistent organic pollutants (POPs) and the plastic particles in Uruguayan beaches (Weinstein et al., 2014a; b). This connection has not been addressed in the context of waste management in Uruguay, but has already been highlighted internationally (e.g. Frias et al. 2010; Hirai et al. 2011; Heskett et al. 2012; Antunes et al. 2013). 


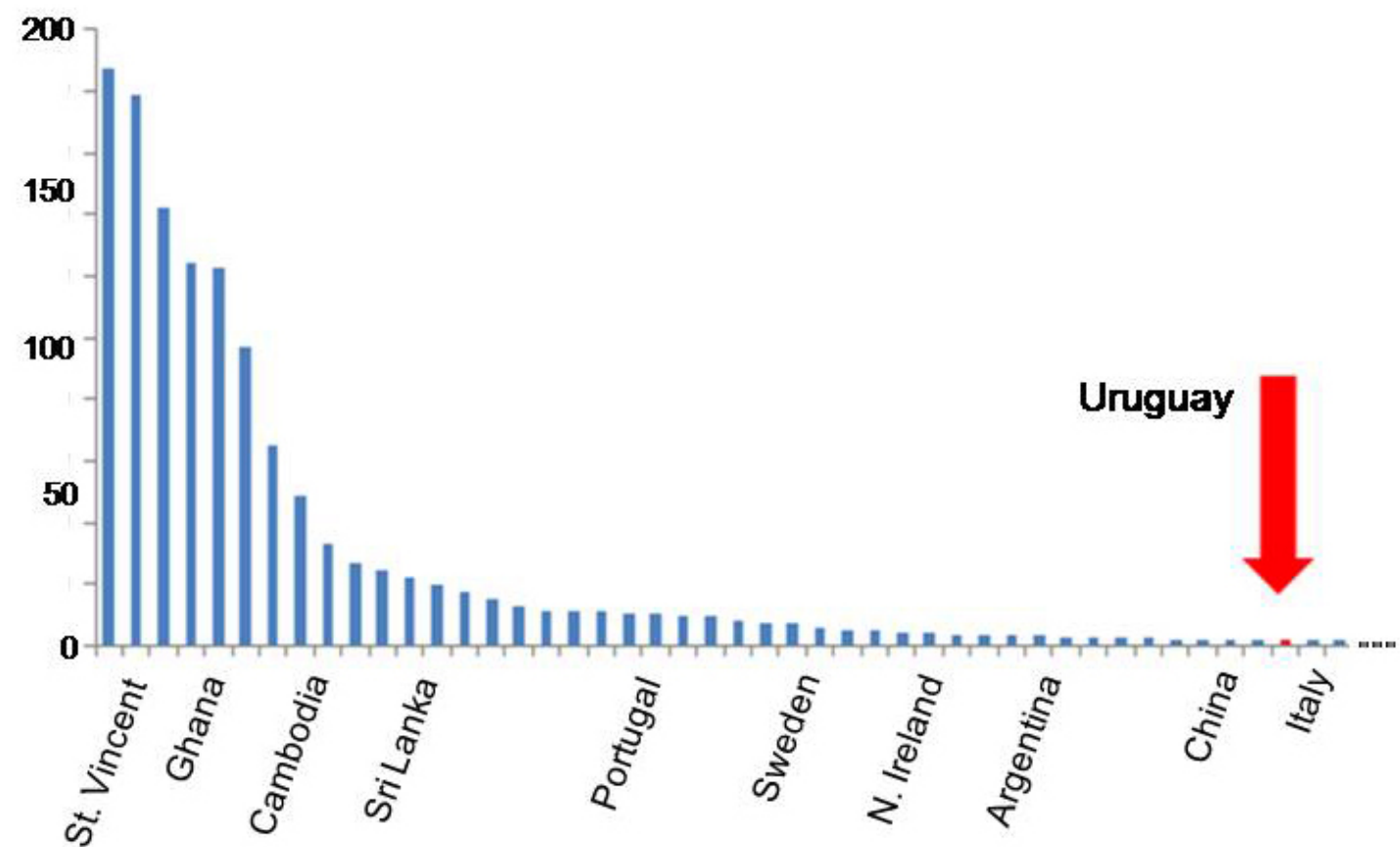

Figure 4 - Histogram showing the global Standardized Ocean Trash Index (SOTI), based on information collected by volunteers during the Ocean Cleanup Day 2011. The arrow indicates were Uruguay ranks in relation to other countries. See text for details. Data available from http://www.oceanconservancy.org

Figura 4 - Histograma mostrando o Índice Global Padronizado Oceano Trash (SOTI), com base em informações coletadas por voluntários durante o Cleanup Day Oceano 2011. A seta indica o lugar que ocupa Uruguai em relação a outros países. Veja o texto para mais detalhes. Dados disponíveis a partir de http://www.oceanconservancy.org

b) Benthic debris characterization and quantification

In order to quantify and characterize benthic marine debris in the Atlantic Ocean and Río de la Plata Estuary, the National Direction of Aquatic Resources (DINARA) has been recording marine debris collected by bottom trawl during fisheries assessment surveys since 1999 (González et al., 2014). During these surveys, trawled marine debris of large and very large sizes (i.e. $>10 \mathrm{~cm}$ ) were recorded and classified by material and usage, while associated organisms were also recorded. Earlier data (1999 to 2012) recorded mainly the conspicuous objects, while from 2012 to date a systematic observations of debris were performed, including also small pieces.

Overall, 430 objects have been collected in the 474 trawls performed during 11 surveys ( 5 in the inner and 6 in the outer continental shelf, i.e., in depth $>50 \mathrm{~m}$ ) conducted from 1999 to 2013. Results have shown plastics as the most abundant debris on the seafloor, representing the $83 \%$ of benthic debris in the whole area, with a minor proportion of glass, manufactured wood, textile, rubber and others. Regarding debris classified by its usage, proportions were dependent on the zone (inner or outer continental shelf) with a higher proportion of packaging objects (containers, plastic bags, bottles, etc.) in the inner zone (72\%) than in the outer one (34\%), where objects associated to fishing activities were dominant (47\%). This is in agreement with previous regional studies, where the main items found in riverside and estuarine bottoms were plastic bags $(55 \%$ of total items), assorted plastics $(22 \%)$ and cans (5\%) (e.g., Acha et al. 2003). The presence of debris associated with marine traffic suggests the ineffectiveness or low enforcement of international regulations in Uruguayan waters (e.g., MARPOL). Continuous monitoring of benthic items and its sources is critical in order to assess and improve the enforcement of these regulations.

\section{c) Interactions among plastic debris and aquatic biota}

Although studies covering plastic pollution are quite recent in Uruguay, there is information available on impacts on the marine biota, and ongoing research on this topic. First known reports of anthropogenic residuals in the digestive tract of aquatic animals for the region were made in 2001 (Calvo et al. 2003; Rios \& Feijoó, 2007). These authors found that, during 19992001 and $2005-2006,11.5 \%$ of 26 stranded juvenile green turtles (Chelonia mydas) had debris in their digestive tracks. It was not until a couple of years later that Murman et al. (2011) and Vélez-Rubio et al., 
(2013) found that green turtles could be impacted more than expected by plastic pollution. Plastic debris, were found in more than $70 \%$ of the analyzed individuals and ingestion of solid waste items was the main cause of death of stranded specimens, even exceeding deaths caused by interaction with fisheries (Alonso \& VélezRubio, 2011; Vélez-Rubio et al., 2013). Furthermore, juvenile individuals (i.e. carapace length $<$ than $35 \mathrm{~cm}$ ) were the most affected by this interaction (Murman et al., 2011; Vélez-Rubio et al., 2013). The same pattern was also observed regionally in juvenile green turtles in Argentina (González-Carman et al., 2014) and in the Río de la Plata Dolphin (Pontoporia blainvilei) (Denuncio et al., 2011) in Argentina. These authors conclude that this phenomenon is due to the great availability of debris in the Río de la Plata estuary, especially in the turbidity front area. Moreover, the younger the individual the lower its capacity to distinguish between plastics and real food (Denuncio et al., 2011; González-Carman et al., 2014).

Recently, the analysis of 806 pellets of a Kelp Gull (Larus dominicanus) colony located on Isla de las Gaviotas (on the coast of the Río de la Plata) between 2011 and 2013, showed that inorganic matter was the third most important item in percentage of frequency of occurrence. Moreover, plastic debris represented the $60.2 \%$ of the total weight of this inorganic matter. In addition, the latter were the third most important item in percentage of frequency of occurrence (Burgues et al. 2014). But coastal seabirds are not the only group affected by plastics ingestion. A recent conventional diet analysis from 128 Diomedea and Thalassarche albatrosses incidentally caught in fisheries operating in Uruguayan (mainly in the shelf break and deep waters) and adjacent waters of the South-western Atlantic Ocean showed that $16.4 \%$ of the digestive tracts had marine debris (Jiménez et al. 2014). The most common type was plastic fragments, but some fisheries-related items were also recorded.

Although there are no published studies for Uruguay reporting plastic ingestion on marine fishes, plastic ingestion has been recently addressed on a community of freshwater fishes. A study on the fish food web in Barra Falsa Stream, a watercourse that flows into the outer Río de la Plata (Maldonado-Uruguay) revealed the presence of microplastics in the digestive tracts of eight species (Machín et al. 2014). Detritivore and omnivore species were the ones who showed the highest numbers of plastic debris. The presence of plastic debris in the digestive tracts was significantly

greater in fishes collected during winter than in those collected in summer, probably due to changes in food availability. This is the first record of plastic debris in the diet of freshwater fishes in Uruguay.
Anthropogenic debris, from both land and marine-based sources, also constitute abundant, persistent and highly buoyant substrata attractive for varied biota (Thiel \& Gutow, 2005a; Murray, 2009). This biota includes both facultative (i.e. inhabitants of benthic substrata in the coastal zone that can colonize floating objects) and obligate rafting species (i.e., only present on floating objects and sometimes on megafauna) (Thiel \& Gutow, 2005; Scarabino et al., 2014). Published data of biota associated with floating substrates is scarce for Uruguayan waters although their presence in the Uruguayan coast, notably on anthropogenic debris, is a very common phenomenon. Anthropogenic debris colonized by this fauna is likely related to subtropical waters, both because of the fauna involved is typical of these waters, as well as it usually matches the occurrence of blue plankton stranded in the Uruguayan coast (i.e., austral summer, during maximum influence of Subtropical waters in the area). Among obligate rafting taxa recorded, the following are highlighted for their abundance and/or singularity: Lepas, Planes (Crustacea Cirripedia and Decapoda), Fiona, Litiopa (Gastropoda) and Amphinome (Polychaeta). Moreover, there is a recurrent presence of facultative species of Caprella (Amphipoda), Obelia (Hydrozoa), Conopeum (Bryozoa), Amphibalanus, Megabalanus (Cirripedia) and Stylocheilus (Gastropoda) (Scarabino et al., 2014). For Hydrozoa, the only taxonomic group analysed in detail, three species of hydrozoan polyps were reported (mostly represented by Obelia dichotoma) associated with anthropogenic floating objects (mainly plastics) stranded on the east coast of Uruguay (Leoni, 2014). These are within their reported distributional range (Genzano, 1994, Genzano et al., 2009, Miranda et al., 2011) and occur also on natural hard substrata in the study area (Milstein, 1976; Leoni, 2014). Two byssate bivalves, Pinctada imbricata and Isognomon bicolor, have been found in several occasions associated to floating debris in the Uruguayan coast (i.e., ca. $34^{\circ} \mathrm{S}$ ) (Breves et al., 2014; Marques \& Breves, 2014). Both species live otherwise attached to natural substrata on rocky shores in the north of Santa Catarina, Brazil $\left(28^{\circ} \mathrm{S}\right)$, being $I$. bicolor an invasive species along the Brazilian coast. None of these species have been found on rocky shores of Uruguay, thus underlining the importance of rafting as a potential dispersion mechanism for invasive species.

The manifold increase of floating debris in the marine environment in the last decades could expand the range of distribution of many marine species (Thiel \& Haye, 2006) or enhance the dispersal of exotic species, with negative effects on native marine biodiversity (Derraik, 2002; Barnes \& Fraser, 2003; Bax et al., 2003; Barnes \& Milner, 2005; Murray, 2009). We thus stress the importance of conducting detailed taxonomic and 
faunistic studies and quantitative analysis of this fauna and its temporal dynamics in order to elucidate the origin and dispersal of floating debris on the coast.

Regarding the colonization of benthic debris by invertebrates, isolated observations in the inner and outer Uruguayan shelf (including the Río de la Plata) during 1997-2007, and a systematic record between 2010 and 2013, showed contrasting patterns. Large (more than $15-20 \mathrm{~cm}$ ) and rigid debris (mainly plastic containers) were inhabited by a diverse epibenthic assemblage in the inner shelf, similar to that found colonizing natural substrata. However, in the outer shelf a poor (mainly anemones) and different assemblage from the natural microsubstrata (mainly shells) was present on the sunken buoys, bottles and containers found. The former includes polychaetes (mainly the serpulid Hydroides $s p$.), barnacles (Amphibalanus sp.), incrusting bryozoans, bivalves, polyplacophorans, sessile gastropods (the calyptraeids Crepidula sp. and Bostrycapulus sp.) and even large gastropods ovipositioning (Cymatium parthenopeum and the exotic Rapana venosa) and small octopuses (Octopus tehuelchus) living inside the debris. On the other hand, small (less than $15-20 \mathrm{~cm}$ ) and/or flexible debris (i.e. nylon, ropes, fabric), were colonized in both inner and outer shelf by fast growing organisms benthic invertebrates or juveniles mostly mytilids, barnacles (Amphibalanus sp.) or hydroids.

\subsection{Policy}

\section{a) International agreements on marine pollution prevention}

On a regional scale, there are two relevant bi-national treaties with Argentina, one concerning the Uruguay River, which addresses the uses of the river and pollution issues, and another about the Río de la Plata and its Maritime Front. The latter has been incorporated as National Law N. ${ }^{\circ} 14,145$ in January $25^{\text {th }} 1974$. In this law, Article 49 requires the parties (Argentina and Uruguay) to prevent water pollution. In this line, the Executive Order $N^{\circ} 100 / 991$ (1991) "Regulations governing use of water, coastal and port areas" (Articles 38 and 118) empowers the National Maritime Authority to impose fines for pollution caused by garbage.

On an international scale, Uruguay is signatory of the "International Convention for the Prevention of Pollution from Ships (1973), as modified by the Protocol of 1978 (MARPOL 73/78)". Therefore several national regulations have been adopted on this issue as the National Law $\mathrm{N}^{\circ} 14,885$ (April $25^{\text {th }}$ 1979). In this line, and in accordance with Regulation 9 Annex V of this international convention, the Uruguayan Maritime Provision $\mathrm{N}^{\circ} 80$ establishes the "rules to prevent pollution by dumping waste from ships operating in waters under national jurisdiction". Plastic is recognized as a distinct garbage type, and deliberate dumping is banned in all aquatic environments, including inland water bodies. Therefore, each discharge operation or completed incineration must be registered, including discharges at sea, at reception facilities, or in other ships. If any accidental or exceptional garbage discharge occurs, the accident time, position (or port) of the ship, the estimated amount and category of garbage, and circumstances of disposal, escape or loss must be reported.

In addition, in 1982 Uruguay signed the United Nations Convention on the Law of the Sea (UNCLOS) that sets the legal framework within which all activities in the oceans and seas must be carried out. In this sense, Uruguay incorporated this UN Convention with the national Law $\mathrm{N}^{\circ} 16,287$ (July 29th 1992), and the national Law $\mathrm{N}^{\circ} 16,688$ (26/XII/94) that includes a "Prevention and Surveillance Scheme to possible contamination of the waters of national jurisdiction", which in its Articles 2 and 3 clearly defines the responsibilities for protection of aquatic environment.

\section{b) National legislation on plastic management}

The Uruguayan law recognizes that the main problem of plastics is management (i.e., collection, final disposal, recycling), and the economic costs associated with it. The costs of this management are transferred from producers and consumers to the society as a whole. In Uruguay, local governments are responsible for waste collection and final deposition. Thus, when waste amount increases their expenses increase as well, leading us to what classical economy identifies as negative externalities of a productive activity (Pigou, 1920). How and who should bear these costs is an issue that has generated different analyses, although there is still no scientific consensus on the topic.

The Uruguayan regulatory framework on plastic disposal was inspired on European Directives, and especially on the Spanish Packaging Act (i.e., European Parliament and Council Directive 94/62/EC on packaging and packaging waste) (Parliament of Uruguay Act, 2004). Here, plastic is not considered a domestic (or consume) waste but an industrial debris. Hence, manufacturers are not only responsible for the waste generated by the industrial activity, but also of debris generated by manufactured and sold products (i.e., Extended Producer Responsibility).

In this context, Law $\mathrm{N}^{\circ} 17,849(29 / 11 / 2004)$ declares in the public interest the protection of the environment against damages arising from plastic waste management, enabling the limitation of individual rights as the environment is protected by the Constitution. Thus, the principles of the Uruguayan environmental policy framework set forth in the Environmental Protection Act $\left(\mathrm{N}^{\circ} 17\right.$ 283) expressly incorporate prevention and forethought, gradual and progressive inclusion, social participation from various sectors, adequate 
environmental information, and international insight. This law involves post-consumption regulations, but also restricts their use. The Ministry of Housing, Spatial Planning and Environment (MVOTMA) is empowered to adopt measures to select the most appropriate packaging types with the least environment impact and thus prevent waste generation, "...promoting the reuse, recycling and other forms of recovering packaging waste, in order to avoid or reduce their disposal, especially as part of the common or domestic solid waste" (Article 1).

The Ministry of Housing, Spatial Planning and Environment (MVOTMA), National Customs (Ministry of Economy and Finances) and Local Governments are responsible of both enforcement and control of this law. The standard refers to packaging and packaging waste placed on the market and generated in Uruguay, including imported plastic. MVOTMA will establish terms and conditions for the implementation of the mandates of the law. Not all containers have the same environmental consequences, the same urgency, or the same treatment priority. Hence, the law provides room for future management development, empowering MVOTMA to refine the law (e.g., by product type, packaging or region) establishing adjustment periods, adequacy and effectiveness. However, packaging and waste that are exclusive of industrial, commercial or agricultural activities are subject to specific regulations (Decree $\mathrm{N}^{\circ}$ 152/2013 and 182/2013).

The law considers several stakeholders, with obligations for consumers, manufacturers and packers, including packaging importers. On the other hand, with fewer responsibilities, sellers and transporters of plastic-packaged goods are also included. Thus the law seeks to involve all actors, activities or actions related to plastic, in order to assign responsibilities in a more equitable way and improve efficiency in implementation. In this line, is necessary to be registered at the MVOTMA to sell and purchase plastics products and/or raw material for its manufacture. This seeks to identify the manufacturing chain of packaging for all economic stakeholders, as well as to gain knowledge about final users via manufacturer's sales information. In addition, manufacturers, importers and packers registered will be responsible to implement a management plan to ensure the proper disposal of plastics once put on the market. Those who were not registered, nor have an approved management plan complying with objectives established in regulations (i.e. reduce generation of containers, re-use, recycle) will not be able to commercialize their products in the market. To guarantee this, Articles 10 and 11 of Law $\mathrm{N}^{\circ} 17,849$ established controls and sanctions prohibiting import, manufacture and marketing of plastics, as well as severe fines if these obligations were not met.

\section{Conclusions and perspectives}

Here we show that, despite the limited social awareness, Uruguay is not an exception to the global environmental issues associated with plastic debris in aquatic systems. This review highlights urban wastes (e.g., open sky landfills) as the main source from land of plastic debris, and the urgent need to improve its management. Montevideo and its Metropolitan Area are the main source in Uruguay, with plastics being the second most important type of residue (i.e., 14\%). While waste management is a key aspect on plastic debris destiny, both the reduced distance between landfills and waterways, and the open dumps seems critical for Uruguayan waste management processes. Landfills are a constant source of plastic materials to aquatic ecosystems. Industry is also an important waste generator. In some cases, plastic production is not significant and is recycled and reused (e.g., tanneries, wool washers, paint factories, telecommunications, agrochemical industry) (FICHTNER-LKSUR-Asociados, 2004). However, in some cases, plastic waste is not processed and disposed properly, releasing highly toxic chemical waste or becoming a source of contamination of waterways (e.g., transported via streams and rivers), and the Río de la Plata Estuary. This debris arrives to the ocean, increasing its dispersion, and thus their impacts on biodiversity.

Furthermore, plastics also come from the ocean. Maritime traffic in Uruguayan waters has increased in the last years, and it is known that vessels generate much of the debris found in remote coasts and the seabed. In the last year the Uruguayan maritime zone received almost 1,160 ships per month, and this should be of concern. Continuous monitoring programmes of benthic litter and its sources are critical in order to assess the effectiveness of the international regulations. Also, accurate estimates of the amount of garbage produced by those ships are necessary for the development and improvement of waste management plans of municipalities and port authorities. Thus, although Uruguay has an updated and modern legislation on plastics, it remains necessary to avoid oversight and enforce proper waste management. Education and awareness of final users, whose importance should not be neglected, should also be prioritized, as well.

Watersheds and coastal areas should be managed as a whole. But besides this 'spatial integration', plastic waste problems should be also treated in an interdisciplinary and integrated framework, calling civil society, private companies, NGOs, decision makers (local and national) and academia. While, as has been showed, there are currently several projects under development in the country, collaboration and coordination between these is essential and should be 
encouraged. Information, dissemination and research on plastic debris and its consequences on the environment must be urgently addressed.

In Uruguay, institutional public awareness efforts in coastal areas are mainly headed by the EcoPlata Program. This program is now incorporated in the Environmental National Agency (DINAMA-MVOTMA), and joined the International Coastal Cleanup Day since 2009 as the national coordinator. This international event is organized by Ocean Conservancy since 1986, and is currently developed in more than 150 countries. This activity focuses on community engagement, with hundreds of thousands of volunteers worldwide spending a day collecting garbage in their local beaches. Volunteers register the type and amount of residues found and thus generate information that is systematized and shared globally.

However, this information and dissemination efforts should be complemented and based on 'ad hoc' scientific knowledge. Although studies on plastic pollution are quite recent in Uruguay, there is some information available on its impacts on the marine biota. Even if this subject is not fully considered by ecologists as a priority research (Ivar do Sul \& Costa, 2007) and most biologists involved used to be focused on charismatic species (e.g. birds, sea mammals, sea turtles), this trend is changing in the last years. Research assessing effects of plastic wastes in the ecology of ecosystems provide key information that may be critical for management and mitigation of their effects. Therefore, scientific research on this topic should be promoted, since the generated knowledge is of great importance for the (near) future when inevitably this risk will be addressed in Uruguay. It is particularly important to consider integrated and interdisciplinary approaches, looking at the big picture and the several dimensions of the problem, even if the most paradigmatic are related to environmental or marine and coastal management.

Probably the main problem of plastics debris is that the costs of its management are transferred from producers and consumers to society as a whole. However, although the Uruguayan legislation recognizes that fact and includes modern and internationally recognized concepts on plastic management, the real application of established incentive, control and enforcement capability legally available seems very shy. In this sense, the situation in Latin America would not be much different, so inter-state initiatives to reduce the probability of plastic arriving to aquatic ecosystems seems also necessary.

Simply stated, the most straightforward solution to the plastic debris problem should be minimize or stop the input of non-degradable plastics in aquatic systems. In this line, we stress that the global and regional hydrographical setting, as well as idiosyncratic ecological, socio-economic and cultural issues, makes Uruguay a valuable test-site to assess: a) the relative importance of international, regional and national-level policies in plastic debris quantity and quality, b) the impact of initiatives to keep track on the source, dynamics and impacts of plastic and microplastic debris in aquatic systems in the context of a watershed dynamics, c) the level of public engagement with this policies, and d) impacts on biodiversity and ecosystem goods and services.

\section{Acknowledgments}

The authors wish to thank Professor Martin Thiel for helpful and constructive comments that significantly improve the manuscript. Thank are extended to Bruno Figueiredo for Portuguese translation, the Dirección Nacional de Recursos Acuáticos (DINARA), the Crew of B/I Aldebaran (DINARA), Averaves, Karumbé, CIMAR, and InvBiota NGOs, Idea Wild for the donation of equipments for seabirds' diet analyses, and the Agencia Nacional de Investigación e Innovación (ANII-Iniciación a la Investigación Grant), CSICUdelaR (Programa de Apoyo a la Investigación Estudiantil-PAIE) for the financial support of several of the projects presented in this paper. The finalized text was greatly assisted by insightful comments of the Editor and two anonymous reviewers.

\section{References}

Acha, E.M.; Mianzan, H.W.; Iribarne, O.; Gagliardini, D.A.; Lasta, C.; Daleo, P. (2003) - The role of the Río de la Plata bottom salinity front inaccumulating debris. Marine Pollution Bulletin, 46(2):197-202. DOI: 10.1016/S0025-326X(02)00356-9.

Alonso, L.; Vélez-Rubio, G. (2011) - Causas de mortalidad en juveniles de Chelonia mydas en el Área Costero-Marina Protegida "Cerro Verde e Islas de la Coronilla", Uruguay. Proceedings of the $5^{\text {th }}$ Jornada de Pesquisa e Conservação de Tartarugas Marinhas do Atlantico Sul Ocidental (ASO), pp.3538, Florianópolis, SC, Brazil. Available on-line at http://www.seaturtle.org/pdf/ocr/TAMAR_2011_ResumosVJornadasAS O.pdf

Andrady, A.L. (2003) - Plastics and the Environment. 792p., John Wiley \& Sons, Inc., New Jersey, USA. ISBN 0-471-09520-6.

Andrady, A.L. (2011) - Microplastics in the marine environment. Marine Pollution Bulletin, 62(8):1596-1605. DOI: 10.1016/j.marpolbul.2011.05.030.

Andrady, A.L.; Neal, M.A. (2009) - Applications and societal benefits of plastics. Philosophical Transactions of the Royal Society B, 364(1526):1977-1984. DOI: 10.1098/rstb.2008.0304.

Antunes, J.C.; Frias, J.G.L.; Micaelo, A.C.; Sobral, P. (2013) Resin pellets from beaches of the Portuguese coast and adsorbed persistent organic pollutants. Estuarine, Coastal and Shelf Science, 130(20):62-69. DOI: 10.1016/j.ecss.2013.06.016.

Arthur, C.; Baker, J.; Bamford, H.; Barnea, N.; Lohmann, R.; McElwee, K.; Morishige, C.; Thompson, R. (2009) - Executive Summary. Proceedings of the International Research Workshop on the Occurrence, Effects, and Fate of Microplastic Marine Debris, pp.7-17, Arthur, C.; Baker, J.; Bamford, H. (eds.), National Oceanic and Atmospheric Administration (NOAA), Marine Debris Division, Technical Memorandum NOS-OR\&R30, Silver Spring, MD, U.S.A. Available on-line at http://marinedebris.noaa.gov/sites/default/files/Microplastics.pdf

Astudillo, J.C.; Bravo, M.; Dumont, C.P.; Thiel, M. (2009) Detached aquaculture buoys in the SE Pacific: potential dispersal vehicles for associated organisms. Aquatic Biology, 5(3):219-231. DOI: 10.3354/ab00151. 
Azzarello, M.Y.; van Vleet, E.S. (1987) - Marine birds and plastic pollution. MEPS - Marine Ecology Progress Series (ISSN: 1616-1599), 37:295-303, Inter-Research Science Center (IR), Oldendorf/Luhe, Germany. Available on-line at http://www.intres.com/articles/meps/37/m037p295.pdf

Barnes, D.K.A.; Fraser, K.P.P. (2003) - Rafting by five phyla on man-made flotsam in the Southern Ocean. MEPS - Marine Ecology Progress Series (ISSN: 1616-1599), 262:289-291, InterResearch Science Center (IR), Oldendorf/Luhe, Germany. Available on-line at http://www.int-res.com/abstracts/meps/v262/p289-291/

Barnes, D.K.A.; Galgani, F.; Thompson, R.C.; Barlaz, M. (2009) Accumulation and fragmentation of plastic debris in global environments. Philosophical Transactions of the Royal Society B, 364(1526):1985-1998. DOI: 10.1098/rstb.2008.0205.

Barnes, D.K.A.; Milner, P. (2005) - Drifting plastic and its consequences for sessile organism dispersal in the Atlantic Ocean. Marine Biology, 146(4):815-825. DOI: 10.1007/s00227-0041474-8.

Bax, N.; Williamson, A.; Aguero, M.; Gonzalez, E.; Geeves, W. (2003) - Marine invasive alien species: a threat to global biodiversity. Marine Policy, 27(4):313-323. DOI: 10.1016/S0308597X(03)00041-1.

Boerger, C.M.; Lattin G.L.; Moore, S.L.; Moore, C.J. (2010) Plastic ingestion by planktivorous fishes in the north pacific central gyre. Marine Pollution Bulletin, 60(12):2275-2278. DOI: 10.1016/j.marpolbul.2010.08.007.

Bravo, M.; Astudillo, J.C.; Lancellotti, D.; Luna-Jorquera, G.; Valdivia, N.; Thiel, M. (2011) - Rafting on abiotic substrata: properties of floating items and their influence on community succession. MEPS - Marine Ecology Progress Series (ISSN: 16161599), 439:1-17, Inter-Research Science Center (IR), Oldendorf/Luhe, Germany. Available on-line at http://www.intres.com/articles/feature/m439p001.pdf

Breves, A.; Scarabino, F.; Leoni, V. (2014) - First records of the non-native bivalve Isognomon bicolor (C. B. Adams, 1845) rafting to the Uruguayan coast. CheckList: The Journal of Biodiversity Data, 10(3):684-686. DOI: 10.15560/10.3.684.

Bullimore, B.A.; Newman, P.B.; Kaiser, M.J.; Gilbert, S.E.; Lock, K.M. (2001) - A study of catches in a fleet of 'ghost-fishing' pots. Fishery Bulletin (ISSN: 0090-0656), 99:247-253, National Marine Fisheries Service (NMFS) Scientific Publications Office (SPO), Seattle, Washington, U.S.A. Available on-line at http://fishbull.noaa.gov/992/992toc.htm

Burgues, M.F.; Machín, E.; Teixeira de Mello, F.; Carrizo, D.; Lenzi, J. (2014) - Consumo de plásticos por la gaviota cocinera (Aves, Laridae, Larus dominicanus) en Isla de las Gaviotas (Montevideo, Uruguay). Proceedings of the Tercer Congreso Uruguayo de Zoología "Prof. Dr. Raúl Vaz-Ferreira [Resúmenes], pp.42, Facultad de Ciencias, Universidad de la República, Montevideo, Uruguay. Available on-line at http://cuz.szu.org.uy/Libro\%20resumenes\%20IIICUZ.pdf

Burone, L.; Ortega, L.; Franco-Fraguas, P.; Mahiques, M.; GarcíaRodriguez, F.; Venturini, N.; Marin, Y.; Brugnoli, E.; Nagai, R.; Muniz, P.; Bícego, M.; Figueira, R.; Salaroli, A. (2013) - A multiproxy study between the Río de la Plata and the adjacent South-western Atlantic inner shelf to assess the sediment footprint of river vs. marine influence. Continental Shelf Research, 55:141-154. DOI: 10.1016/j.csr.2013.01.003.

Calvo, M.V.; Lezama, C.; López-Mendilaharsu, M.; Fallabrino A.; Coll, J. (2003) - Stomach content analysis of stranded juvenile green turtles in Uruguay. Proceedings of the 22nd Annual Symposium of Sea Turtle Biology and Conservation, pp.203, Seminoff, J.A., compiler, National Oceanic and Atmospheric Administration (NOAA) Technical Memorandum, NMFSSEFSC-503, Miami, Florida, U.S.A. Available on-line at http://seaturtlesociety.com/proceedings.html
Clapham, P.J.; Young, S.B.; Brownell, J.R. (1999) - Baleen whales: conservation issues and the status of the most endangered populations. Mammal Review, 29(1):35-60. DOI: 10.1046/j.13652907.1999.00035.x.

Cole, M.; Lindeque, P.; Halsband, C.; Galloway, T.S. (2011) Microplastics as contaminants in the marine environment: A review. Marine Pollution Bulletin, 62(12):2588-2597. DOI: 10.1016/j.marpolbul.2011.09.025.

Committee on Shipborne Wastes (1995) - Clean ships, clean ports, clean oceans: controlling garbage and plastic wastes at sea. 384p., National Academies Press, Washington, CD, U.S.A. ISBN: 978-0309051378. Available on-line at http://www.nap.edu/catalog/4769/clean-ships-clean-ports-clean-oceanscontrolling-garbage-and-plastic

Cózar, A.; Echevarría, F.; González-Gordillo, I.; Irigoien, X.; Úbeda, B.; Hernández-León, S.; Palma, A.T.; Navarro, S.; García-de-Lomas, J.; Ruiz, A.;Fernández-de-Puelles, M.L.; Duarte, C.M. (2014) - Plastic debris in the open ocean. PNAS, 111(28):10239-10244. DOI: 10.1073/pnas.1314705111.

Denuncio, P.; Bastida, R.; Dassis, M.; Giardino, G.; Gerpe, M.; Rodríguez, D. (2011) -Plastic ingestion in Franciscana dolphins, Pontoporia blainvillei (Gervais and d'Orbigny, 1844), from Argentina. Marine Pollution Bulletin, 62(8):1836-1841. DOI: 10.1016/j.marpolbul.2011.05.003.

Derraik, J.G.B. (2002) - The pollution of the marine environment by plastic debris: review. Marine Pollution Bulletin, 44(9):842-852. DOI: 10.1016/S0025-326X(02)00220-5.

Dubois, J.H. (1972) - Plastics History U.S.A. 447p., Cahners Books, Boston, USA. ISBN: 978-0843612035.

Eriksen, E.; Lebreton, L.C.M.; Carson, H.S.; Thiel, M.; Moore, C.J.; Borerro, J.C.; Galgani, F.; Ryan, P.G.; Reisser, J. (2014) Plastic Pollution in the World's Oceans: More than 5 Trillion Plastic Pieces Weighing over 250,000 Tons Afloat at Sea. PLoS ONE, 9(12):e111913. DOI: 10.1371/journal.pone.0111913.

Erikson, C.; Burton, H. (2003) - Origins and biological accumulation of plastic particles in fur seals from Macquarie Island. Ambio (ISSN: 0044-7447), 32:380-384, Springer on behalf of Royal Swedish Academy of Sciences, Stockholm, Sweden. Available on-line at http://www.jstor.org/stable/4315405

Farrapeira, C.M.R. (2011) - Macrobenthic invertebrates found in Brazilian coast transported on abiogenic solid floating debris. Journal of Integrated Coastal Zone Management / Revista da Gestão Costeira Integrada, 11(1):85-96. DOI: 10.5894/rgci200.

Farrell, P.; Nelson, K. (2012) - Trophic level transfer of microplastic: Mytilus edulis (L.) to Carcinus maenas (L.). Environmental Pollution, 177:1-3. DOI: 10.1016/j.envpol.2013.01.046.

FICHTNER-LKSUR-Asociados (2004) - Residuos Sólidos Urbanos y Anexos (Volume II). Plan Director de Residuos Sólidos de Montevideo y Área Metropolitana. Programa de saneamiento de Montevideo y Área Metropolitana, Montevideo, Uruguay. Available on-line http://www.ciu.com.uy/innovaportal/v/36639/10/innova.front/plan_direc tor_de_residuos_solidos_de_montevideo_y_area_metropolitana.html

Foekema, E.M.; De Gruijter, C.; Mergia, M.T.; van Franeker, J.A.; Murk, A.J.; Koelmans, A.A. (2013) -Plastic in North Sea. Environmental Science \& Technology, 47(15):8818-8824. DOI: 10.1021/es400931b.

Framiñan, M.B.; Brown, O.B. (1996) - Study of the Río de la Plata turbidity front Part I: Spatial and temporal distribution. Continental Shelf Research, 16(10):1259-1282. DOI: 10.1016/02784343(95)00071-2.

Framiñan, M.B.; Valle-Levinson, A.; Sepulveda, H.H.; Brown, O.B. (2008) - Tidal variations of flow convergence, shear, and stratification at the Rio de la Plata estuary turbidity front. Journal of 
Geophysical Research, 113(C8):1-17. DOI: 10.1029/2006JC004038.

Franco-Fraguas, P.; Burone, L.; Mahiques, M.; Ortega, L.; Urien, C.; Muñoz, A.; López, G.; Marin, Y.; Carranza, A.; Lahuerta, N.; de Mello, C. (2014) - Hydrodynamic and geomorphological controls on surface sedimentation at the Subtropical Shelf Front / Brazil-Malvinas Confluence transition off Uruguay (Southwestern Atlantic Continental Margin). Marine Geology, 349:2436. DOI: $10.1016 /$ j.margeo.2013.12.010.

Frias, J.P.G.L.; Sobral, P.; Ferreira, A.M. (2010) -Organic pollutants in microplastics from two beaches of the Portuguese coast. Marine Pollution Bulletin, 60(11):1988-1992. DOI: 10.1016/j.marpolbul.2010.07.030.

Genzano, G.N. (1994) -La comunidad hidroide del intermareal de Mar del Plata (Argentina). I.Estacionalidad, abundancia y periodos reproductivos. Cahiers de Biologie Marine (ISSN 2262-3094), 35:289-303, Station Biologique de Roscoff (CNRS), France. Available in http://www.sbroscoff.fr/cbm/issue.htm? execution=e10s1

Genzano, G.N.; Giberto, D.; Schejter, L.; Bremec, C.; Meretta, P. (2009) - Hydroid assemblages from the Southwestern Atlantic Ocean (34-42 S). Marine Ecology, 30(1):33-46. DOI: 10.1111/j.1439-0485.2008.00247.x.

Giberto, D.A.; Bermec, C.S.; Acha, E.M.; Mianzan, H. (2004) Large-scale spatial patterns of benthic assemblages in the SW Atlantic: the Rio de la Plata estuary and adjacent shelf waters. Estuarine Coastal \& Shelf Science, 61(1):1-13. DOI: 10.1016/j.ecss.2004.03.015.

González-Carman, V.; Acha, E.M.; Maxwell, S.M.; Albareda, D.; Campagna, C.; Mianzan, H. (2014) -Young green turtles, Chelonia mydas, exposed to plastic in a frontal area of the SW Atlantic. Marine Pollution Bulletin, 78(1-2):56-62. DOI: 10.1016/j.marpolbul.2013.11.012.

González, S.; Chocca, J.; Rubio, L.; Scarabino, F.; López, G.; Marín, Y.; Martínez, G. \& Ortega, L. (2014) - Caracterización de los residuos bentónicos en aguas uruguayas. Proceedings of the Tercer Congreso Uruguayo de Zoología "Prof. Dr. Raúl Vaz-Ferreira [Resúmenes], pp.43, Facultad de Ciencias, Universidad de la República, Montevideo, Uruguay. Available on-line at http://cuz.szu.org.uy/Libro\%20resumenes\%20IIICUZ.pdf

Guerrero, R.A.; Acha, E.M.; Framiñan, M.B.; Lasta, C.A. (1997) Physical oceanography of the Río de la Plata Estuary, Argentina. Continental Shelf Research, 17(7):727-742. DOI: 10.1016/S0278-4343(96)00061-1.

Heskett, M.; Takada, H.; Yamashita, R.;Yuyama, M.; Ito, M.; Geok, Y.B.; Ogata, Y.; Kwan, C.; Heckhausen, A.; Taylor, H.; Powell, T.; Morishige, C.; Young, D.; Patterson, H.; Robertson, B.; Bailey, E.; Mermoz, J. (2012) - Measurement of persistent organic pollutants (POPs) in plastic resin pellets from remote islands: Toward establishment of background concentrations for International Pellet Watch. Marine Pollution Bulletin, 64(2):445-448. DOI: 10.1016/j.marpolbul.2011.11.004.

Hirai, H.; Takada, H.; Ogata, Y.; Yamashita, R.; Mizukawa, K.; Saha, M.; Kwan, C.; Moore, C.; Gray, H.; Laursen, D.; Zettler, E.R.; Farrington, J.W.; Reddy, C.M.; Peacock, E.E.; Ward, M.W. (2011) - Organic micropollutants in marine plastics debris from the open ocean and remote and urban beaches. Marine Pollution Bulletin, 62(8):1683-1692. DOI: 10.1016/j.marpolbul.2011.06.004.

Ivar do Sul, J.; Costa, M. (2007) -Marine debris review for Latin America and the Wider Caribbean Region: From the 1970s until now, and where do we go from here? Marine Pollution Bulletin, 54(8):1087-1104. DOI: 10.1016/j.marpolbul.2007.05.004.

Jayasiri, H. B.; Purushothaman, C.S.; Vennila, A. (2013) - Plastic litter accumulation on high-water strandline of urban beaches in
Mumbai, India. Environmental Monitoring and Assessment, 185(9):7709-7719. DOI: 10.1007/s10661-013-3129-z.

Jiménez, S.; Domingo, A.; Brazeiro, A.; Phillips, R.A. (2014) Marine debris ingestion by albatrosses in the Southwest Atlantic. Proceedings of the Tercer Congreso Uruguayo de Zoología "Prof. Dr. Raúl Vaz-Ferreira [Resúmenes], pp.44, Facultad de Ciencias, Universidad de la República, Montevideo, Uruguay. Available on-line at http://cuz.szu.org.uy/Libro\%20resumenes\%20IIICUZ.pdf

Koelmans, A.A.; Besseling, E.; Foekema, E.M. (2014) - Leaching of plastic additives to marine organisms. Environmental Pollution, 187:49-54. DOI: 10.1016/j.envpol.2013.12.013.

Laist, D.W. (1997) - Impacts of marine debris: entanglement of marine life in marine debris including a comprehensive list of species with entanglement and ingestion records. In: Coe, J.M. \& Rogers, D.B. (eds.), Marine Debris, pp.99-139, SpringerVerlag, New York, U.S.A. ISBN: 978-1-4613-8486-1. DOI: 10.1007/978-1-4613-8486-1_10.

Lechner, A.; Keckeis, H.; Lumesberger-Loisl, F.; Zens, B.; Krusch, R.; Tritthart, M.; Glas, M.; Schludermann, E. (2014) - The Danube so colourful: a potpourri of plastic litter outnumbers fish larvae in Europe's second largest river. Environmental Pollution, 188:177-181. DOI: 10.1016/j.envpol.2014.02.006.

Leoni, V. (2014) - Fauna de hidroides (Cnidaria: Hydrozoa) de La Coronilla-Cerro Verde (Rocha, Uruguay): primer inventario y posibles mecanismos de dispersión. 54p., Bachelor in Biological Science Thesis, Fcaultad de Ciencias, Universidad de la República, Uruguay. Unpublished. Available on-line at www.bib.fcien.edu.uy/files/etd/resumen/uy24-16962R.pdf

Machín, E.; Lenzi, J.; Hernández, D.; Teixeira de Mello, F. (2014) Primeros antecedentes de consumo de plástico por peces de agua dulce. Proceedings of the Tercer Congreso Uruguayo de Zoología "Prof. Dr. Raúl Vaz-Ferreira [Resúmenes], pp.44, Facultad de Ciencias, Universidad de la República, Montevideo, Uruguay. Available on-line at http://cuz.szu.org.uy/Libro\%20resumenes\%20IIICUZ.pdf

Mallory, M.L. (2008) - Marine plastic debris in northern fulmars from the Canadian high Arctic. Marine Pollution Bulletin, 56(8):1501-1504. DOI: 10.1016/j.marpolbul.2008.04.017.

Mann, R. (2006) - The local costs to ecological services associated with high seas global transport. In: Davenport, J.; Davenport, J.L. (eds.), The Ecology of Transportation: Managing Mobility for the Environment, pp 25-38, Springer, Netherlands. ISBN: 978-1-4020-4503-5. DOI: 10.1007/1-4020-4504-2_2.

Marques, R.C.; Breves, A. (2014) -First record of Pinctada imbricata Röding, 1798 (Bivalvia: Pteroidea) attached to a rafting item: a potentially invasive species on the Uruguayan coast. Marine Biodiversity Records. DOI: 10.1007/s12526-014-0258-8

Martins, J.; Sobral, P. (2011) - Plastic marine debris on the Portuguese coastline: A matter of size? Marine Pollution Bulletin, 62(12):2649-2653. DOI: 10.1016/j.marpolbul.2011.09.028.

Mascarenhas, R.; Santos, R.; Zeppelini, D. (2004) -Plastic debris ingestion by sea turtle in Paraiba, Brazil. Marine Pollution Bulletin, 49(4):354-355. DOI: 10.1016/j.marpolbul.2004.05.006.

Mato, Y.; Isobe, T.; Takada, H.; Kanehiro, H.; Ohtake, C.; Kaminuma, T. (2001) - Plastic resin pellets as a transport medium for toxic chemicals in the marine environment. Environmental Science \& Technology, 35(2):318-324. DOI: 10.1021/es0010498.

Mianzan, H.; Lasta, C.; Acha, E.; Guerrero, R.; Macchi, G.; Bremec, C. (2001) - The Río de la Plata Estuary, Argentina-Uruguay. In: Ulrich, S.; Björn, K. (eds.), Coastal Marine Ecosystems of Latin America, pp. 185-204, Springer, Berlin Heidelberg, Germany. ISBN 978-3-540-67228-9. Available on-line at http://link.springer.com/chapter/10.1007/978-3-662-04482-7_14. 
Milstein, A. (1976) - Hidroidea de las costas uruguayas. Dusenia (ISSN 0418-1867), 9(3):77-93, Sociedade Paranaense de Ciências Naturais, Curitiba, Brazil.

Miranda, D.A.; Carvalho-Souza, G.F. (2011) - Presença de pellets plásticos em conteúdos estomacais de peixes desembarcados na costa de salvador, Bahia, Brasil. In: Proceedings of the XIV Congresso Latino-Americano de Ciencias do Mar (COLACMAR), Balneário Camboriú, Brasil. Available on-line at $\mathrm{http}: / /$ www.globalgarbage.org/praia/downloads/XIV-COLACMAR2011/1648.pdf

Moore, C. (2008) - Synthetic polymers in the marine environment: a rapidly increasing, long-term threat. Environmental Research, 108(2):131-139. DOI: 10.1016/j.envres.2008.07.025.

Moore, C.J.; Lattin, G.L.; Zellers, A.F. (2011) - Quantity and type of plastic debris flowing from two urban rivers to coastal waters and beaches of Southern California. Journal of Integrated Coastal Zone Management / Revista da Gestão Costeira Integrada, 11(1):65-73. DOI: $10.5894 / \mathrm{rgci} 194$.

Murman, M.I.; Alonso, L.; Pérez, J.E. (2011) - El impacto de los desechos antrópicos en individuos juveniles de Tortuga Verde (Chelonia mydas), Cerro Verde, Uruguay. Proceedings of the $V$ Jornada de Pesquisa e Conservação de Tartarugas Marinhas do Atlântico Sul Ocidental (ASO), pp.64-68, Florianópolis, Brasil. Available on-line www.seaturtle.org/pdf/ocr/TAMAR_2011_ResumosVJornadasASO.pdf

Murray, R.G. (1996) - Plastic 'Scrubbers' in Hand Cleansers: a further (and minor) source for marine pollution identified. Marine Pollution Bulletin, 32(12):867-871. DOI: 10.1016/S0025-326X(96)00047-1.

Murray, R.G. (2009) - Environmental implications of plastic debris in marine settings: entanglement, ingestion, smothering, hangers-on, hitch-hiking and alien invasions. Philosophical Transactions of the Royal Society B, 364(1536):2013-2025. DOI: 10.1098/rstb.2008.0265.

Ortega, L.; Martínez, A. (2007) - Multiannual and seasonal variability of water masses and fronts over the Uruguayan shelf. Journal of Coastal Research, 23(3):618-629. DOI: 10.2112/040221.1.

OSPAR (2009) - Marine Litter in the North-East Atlantic Region: Assessment and Priorities for Response. 127p., OSPAR, London, U.K. ISBN: 978-1906840266. Available on-line at http://www.marinelitternetwork.org/sites/default/files/marine_litter_in_t he_northeast_atlantic_region.pdf

Pierce, K.E.; Harris, R.J.; Larned, L.S.; Pokras, M.A. (2004) - Obstruction and starvation associated with plastic ingestion in a northern gannet Morus bassanus and a greater shearwater Puffinus gravis. Marine Ornithology (ISSN: 1018-3337), 32(2):187-189, Pacific Seabird Group, Honolulu, HI, U.S.A. Available on-line http://www.marineornithology.org/PDF/32_2/32_2_187-189.pdf

Pigou, A.C. (1920) - The economics of welfare. 428p., Macmillan, London, U.K. ISBN: 978-1596059498.

Piola, A.R.; Möller, O.; Guerrero, R.A.; Campos, E.J.D. (2008) Variability of the subtropical shelf front off eastern South America: Winter 2003 and summer 2004. Continental Shelf Research, 28(13):1639-1648. DOI: 10.1016/j.csr.2008.03.013.

Portz, L.; Manzolli, R.P.; Ivar do Sul, J.A. (2011) - Marine debris on Rio Grande do Sul north coast, Brazil: spatial and temporal patterns. Journal of Integrated Coastal Zone Management / Revista da Gestão Costeira Integrada, 11(1):41-48. DOI: 10.5894/rgci187.

Puig, P.; Grünwaldt, P.; González, S. (2010) - Pesquería artesanal de corvina en Uruguay. Frente Maritimo, 21:23-35, CTMFM Comisión Técnica Mixta del Frente Marítimo, Montevideo, Uruguay. Available on-line at http://ctmfm.org/upload/archivoSeccion/puig-et-al-142478168268.pdf
Rech, S.; Macaya-Caquilpán, V.; Pantoja, J.F.; Rivadeneira, M.M.; Madariaga, D.J.; Thiel, M. (2014) - Rivers as a source of marine litter-A study from the SE Pacific. Marine Pollution Bulletin, 82(1-2):66-75. DOI: 10.1016/j.marpolbul.2014.03.019.

Reisser, J.; Shaw, J.; Hallegraeff, G.; Proietti, M.; Barnes, D.K.A.; Thums, M.; Wilcox, C.; Hardesty, B.D.; Pattiaratchi, C. (2014) Millimeter-Sized Marine Plastics: A New Pelagic Habitat for Microorganisms and Invertebrates. PLoS ONE, 9(6):e100289. DOI: 10.1371 journal.pone.0100289.

Ribic, C.A.; Sheavly, S.B.; Rugg, D.J.; Erdmann, E.S. (2010) Trends and drivers of marine debris on the Atlantic coast of the United States 1997-2007. Marine Pollution Bulletin, 60(8):1231-1242. DOI: 10.1016/j.marpolbul.2010.03.021.

Ríos M.; Feijoó M. (2007) - Preliminary research and conservation of the green turtle (Chelonia mydas) along the Valizas-Cabo Polonio protected area. Proceedings of the XXVII International Symposium of Sea Turtles [Abstracts], pp.218. Rees, A.; Frick, M.; Panagopoulou, A.; Williams, K., compilers, Miami, Florida, U.S.A. Available on-line http://seaturtlesociety.com/proceedings.html

Rios, L.M.; Moore, C. (2007) - Persistent organic pollutants carried by synthetic polymers in the ocean environment. Marine Pollution Bulletin, 54(8):1230-1237. DOI: 10.1016/j.marpolbul.2007.03.022.

Scarabino, F.; Leoni, V.; González, S.; Carranza, A.; Clavijo, C. (2014) - Fauna de invertebrados asociada a objetos flotantes en aguas uruguayas. Proceedings of the Tercer Congreso Uruguayo de Zoología "Prof. Dr. Raúl Vaz-Ferreira [Resúmenes], pp.45, Facultad de Ciencias, Universidad de la República, Montevideo, Uruguay. Available on-line at http://cuz.szu.org.uy/Libro\%20resumenes\%20IIICUZ.pdf

Schmid, C.; Garzoli, S.L. (2009) - New observations of the spreading and variability of theAntarctic Intermediate Water in the Atlantic. Journal of Marine Research, 67(6):815-843. DOI: $10.1357 / 002224009792006151$.

Sutherland, W.J.; Clou, M.; Côté, I.M.; Daszak, P.; Depledge, M.H.; Fellman, L.; Fleishman, E.; Garthwaite, R.; Gibbons; D.W.; De Lurio, J.; Impey, A.J.; Lickorish, F.; Lindenmayer, D.; Madgwick, J.; Margerison, C.; Maynard, T.; Peck, L.S.; Pretty, J.; Prior, S.V.; Redford, K.H.; Scharlemann, J.P.W.; Spalding, M.; Watkinson, A.R. (2010) - A horizon scan of global conservation issues for 2010. Trends in Ecology and Evolution, 25(1):1-7. DOI: 10.1016/j.tree.2009.10.003.

Tanaka, K.; Takada, H.; Yamashita, R.; Mizukawa, K.; Fukuwaka, M.; Watanuki, Y. (2013) - Accumulation of plastic-derived chemicals in tissues of seabirds ingesting marine plastics. Marine Pollution Bulletin, 69(1-2):219 -222. DOI: 10.1016/j.marpolbul.2012.12.010.

Teuten, E.L.; Rowland, S.J.; Galloway, T.S.; Thompson, R.C. (2007) - Potential for plastics to transport hydrophobic contaminants. Environmental Science and Technology, 41(22):77597764. DOI: $10.1021 / \mathrm{es} 071737 \mathrm{~s}$.

Teuten, E.L.; Saquing, J.M.; Knappe, D.R.U.; Barlaz, M.A.; Jonsson, S.; Björn, A.; Rowland, S.J.; Thompson, R.C.; Galloway, T.S.; Yamashita, R.; Ochi, D.; Watanuki, Y.; Moore, C.; Viet, P.H.; Tana, T.S.; Prudente, M.; Boonyatumanond, R.; Zakaria, M.P.; Akkhavong, K.; Ogata, Y.; Hirai, H.; Iwasa, S.; Mizukawa, K.; Hagino, Y.; Imamura, A.; Saha, M.; Takada, H. (2009) - Transport and release of chemicals from plastics to the environment and to wildlife. Philosophical Transactions of the Royal Society B, 364(1526):2027-2045. DOI: 10.1098/rstb.2008.0284.

Thiel, M.; Bravo, M.; Hinojosa, I.A.; Luna, G.; Miranda, L.; Núñez, P.; Pacheco, A.S.; Vásquez, N. (2011) - Anthropogenic litter in the SE Pacific: an overview of the problem and possible solutions. Journal of Integrated Coastal Zone Management / Revista 
da Gestão Costeira Integrada, 11(1):115-134. DOI: 10.5894/rgci207.

Thiel, M.; Gutow, L. (2005) -The ecology of rafting in the marine environment I. The floating substrata. In: R. N. Gibson, R. J. A. Atkinson \& J. D. M. Gordon (eds.), Oceanography and Marine Biology: An Annual Review, 42:181-264, CRC Press, Boca Raton, FL, U.S.A. ISBN: 978-0849327278. Available on-line at https://www.researchgate.net/publication/228646899_The_ecology_of_r afting_in_the_marine_environment._I._The_floating_substrata

Thiel, M.; Gutow, L. (2005a) - The ecology of rafting in the marine environment II. The rafting organisms and community. Oceanography and Marine Biology: An Annual Review, 43:279-418, CRC Press, Taylor \& Francis Group, London, U.K. ISBN: 9780-8493-3597-6. Available on-line at http://www.taylorandfrancis.com/books/details/9780849335976/

Thiel, M.; Haye, P. (2006) - The ecology of rafting in the marine environment III. Biogeographicaland evolutionary consequences. Oceanography and Marine Biology: An Annual Review, 44:323-42, CRC Press, Taylor \& Francis Group, London, U.K. ISBN: 978-0-8493-7044-1. Available on-line at http://www.taylorandfrancis.com/books/details/9780849370441/

Thompson, R.C.; Moore, C.; von Saal, F.S.; Swan, S.H. (2009) Plastics, the environment and human health: current consensus and future trends. Philosophical Transactions of the Royal Society B, 364(1526):2153-2166. DOI: 10.1098/rstb.2009.0053.

Tschernij, V.; Larsson, P.O. (2003) - Ghost fishing by lost cod gill nets in the Baltic Sea. Fisheries Research, 64(2-3):151-162. DOI: http://dx.doi.org/10.1016/S0165-7836(03)00214-5. van Cauwenberghe, L.; Janssen, C.R. (2014) - Microplastics in bivalves cultured for human consumption. Environmental Pollution, 193:65-70. DOI: 10.1016/j.envpol.2014.06.010.

Vélez-Rubio, G.M.; Estrades, A.; Fallabrino, A.; Tomás, J. (2013) Marine turtle threats in Uruguayan waters: insights from 12 years of stranding data. Marine Biology, 160(11):2797-2811. DOI: 10.1007/s00227-013-2272-y.

Weinstein, F.; Olivera, Y.; Cedrés, F.; Pereira, M.; Teixeira de Mello, F.; Carrizo, D.; Lozoya, J.P. (2014) - Evaluación y análisis de microplásticos en playas de Punta del Este: caracterización de una potencial contaminación para la fauna marina. Proceedings of the Tercer Congreso Uruguayo de Zoología "Prof. Dr. Raúl Vaz-Ferreira [Resúmenes], pp.46, Facultad de Ciencias, Universidad de la República, Montevideo, $\begin{array}{lll}\text { Uruguay. } & \text { Available } & \text { on-line } \\ \text { http://cuz.szu.org.uy/Libro\%20resumenes\%20IIICUZ.pdf }\end{array}$

\section{Web pages}

ANP (2014) (s/d) - Estadísticas. In: Institucional, Administración Nacional de Puertos (ANP) internet site, Montevideo, Uruguay. Available on-line at: http://www.anp.com.uy/inicio/institucional/cifras/montevideo/estadisti cas/buques/montevideo_arribos_categoria/evolucion_2010_2014/

NPR (2009) - The History of Plastic: From Billiards to Bibs. In: Plastic peril? National Public Radio (NPR) Special Series, Washington, DC, U.S.A. Available on-line at http://www.npr.org/templates/story/story.php?storyId=114331762 